\title{
CHARACTERISTIC OF HORMONAL HOMEOSTASIS IN WOMEN WITH PROFUSE UTERINE FLOODING IN PREMENOPAUSE
}

\begin{abstract}
M.D. Hresko
Abstract. Hormonal deviations which, undoubtedly are the chief trigger mechanism in the development of profuse uterine blooding of the premenopausal age, become secondary components of the pathological process in the future, taking an insignificant part in the formation of individual features of the disease and therefore, are badly correlated with the specific characteristics of their course. First and foremost local functional and morphological changes occupy the leading position, new stromal-mesenchymal relations are formed.
\end{abstract}

Key word: profuse uterine flooding, premenopause, hormonal homeostasis.

Bukovinian State Medical University (Chernivtsi)

Рецензент - проф. О.М. Юзько

Buk. Med. Herald. - 2013. - Vol. 17, № 2 (66). - P. 34-37

Надійшла до редакції 22.02.2013 року

(C) М.Д. Гресько, 2013

УДК 616.12-005.4-052-054(477.85)

О.І. Гулага, В.К. Тащук, О.С. Полянська

\section{РЕССТР ІНФАРКТУ МІОКАРДА НА ПІВНІЧНІЙ БУКОВИНІ: НЕЙРОГОРМОНАЛЬНІ ПОРУШЕННЯ ПРИ ГОСТРІЙ СЕРЦЕВІЙ НЕДОСТАТНОСТІ}

Буковинський державний медичний університет, м. Чернівці

Резюме. У хворих на гострий інфаркт міокарда 3 клінічними проявами гострої серцевої недостатності (Killip II) виявлені вірогідно нижчі показники ударного об'єму крові $(\mathrm{p}<0,01)$, хвилинного об'єму крові $(\mathrm{p}<0,001)$, вірогідно вищі показники рівня альдостерону $(\mathrm{p}<0,05)$ та передсердного натрійуретичного пептиду

Вступ. Незважаючи на те, що концепція нейроендокринної гіперактивації на сьогодні є ключовою в патогенезі гострої серцевої недостатності (ГСН), справжнє діагностичне значення окремих компонентів нейроендокринних систем у діагностиці та прогнозуванні перебігу серцевої недостатності (CH) не встановлено [2]. Доведено, що циркуляторний рівень норадреналіну, реніну, ангіотензину II, альдостерону, ендотеліну-1 тісно корелює як з тяжкістю, так і з прогнозом IXC [5, 7], однак концентрації нейрогормонів часто виявляються непередбачуваними навіть у однорідній групі зіставлення. Окрім того, рівень нейрогормонів суттєво змінюється під впливом діуретиків, вазодилататорів, інгібіторів АПФ, b-адреноблокаторів, що створює проблеми для їх інтерпретаціï, обмежує діагностичну цінність $[1,5]$. Це зумовлює необхідність проведення досліджень із виявленням множинних кореляційних зв'язків між клінічними і біохімічними показниками при гострому інфаркті міокарда (ГІМ) 3 проявами $\Gamma \mathrm{CH}$.

Мета дослідження. Вивчити особливості внутрішньосерцевої гемодинаміки та нейрогор- $(\mathrm{p}<0,05)$. Виявлений негативний корелятивний зв'язок концентрації передсердного натрійуретичного пептиду 3 величиною ударного об'єму крові $(\mathrm{p}<0,05)$, фракцією викиду $(\mathrm{p}<0,01)$ та хвилинним об'ємом крові $(\mathrm{p}<0,05)$.

Ключові слова: гострий інфаркт міокарда, гормони, ехокардіографія.

мональні аспекти у хворих на гострий інфаркт міокарда з гострою серцевою недостатністю.

Матеріал і методи. Групу дослідження склали 106 пацієнтів, які перебували на стаціонарному лікуванні 3 приводу гострого Q-ГІМ 3 ГСН. Діагноз верифіковано згідно зі стандартами Українського товариства кардіологів [3]. Середній вік хворих склав 51,5 $\pm 3,94$ року. У всіх діагностовано хронічну хворобу нирок на тлі хронічного пієлонефриту у фазі ремісії. Визначення параметрів функціонального стану міокарда проводили за допомогою ехокардіографії (ЕхоКГ) 3 парастернальної та апікальної позиції по короткій та довгій осі з наступним розрахунком показників кардіогемодинаміки: кінцевий діастолічний розмір лівого шлуночка (КДР), кінцевий систолічний розмір лівого шлуночка (КСР), товщина міжшлуночкової перегородки в систолу та в діастолу (ТМШПс та ТМШПд), наприкінці діастоли ЛШ визначали товщину задньої стінки лівого шлуночка в систолу та в діастолу (ТЗСЛШ). За формулами вираховували ряд показників - фракцію викиду (ФВ), кінцевий діастолічний об'єм (КДО), кінцевий систолічний об'єм (КСО), удар- 
ний об'єм (УО), масу міокарда лівого шлуночка (MM) та індекс маси міокарда лівого шлуночка (IMM).

Окрім загальноклінічних та інструментальних обстежень, у всіх хворих імуноферментним методом визначали рівні гормонів: альдостерону, ангіотензинперетворюючого фактору (АПФ), передсердного натрійуретичного пептиду (ПНУП) та фактору Віллебранда (ФВб).

Статистична обробка результатів досліджень проводилась 3 використанням електронних таблиць Microsoft® Office Excel (build 11.5612.5703), програми для статистичної обробки Statgraphics Plus5.1 Enterprise edition (®Statistical Graphics corp. 2001).

Результати дослідження та їх обговорення. На сучасному етапі ЕхоКГ дозволяє не тільки кількісно визначити функціональні параметри, виявити зміну розмірів серцевих структур $[4,8]$, а також за допомогою методу X-Strain отримати значення поздовжної, циркулярної та радіальної деформації, швидкості деформації лівого шлуно- чка $[1,9]$, що дає можливість ранньої діагностики міокардіальної дисфункції. Встановлено (табл.1), що в пацієнтів при ГІМ з Killip II УО був вірогідно нижчим за такий у пацієнтів 3 Killip I $(47,85 \pm 3,53$ проти $64,55 \pm 3,09$ мл, $\mathrm{p}<0,01)$. ФВ у цих пацієнтів також була вірогідно нижчою $(45,05 \pm 0,10$ проти $55,99 \pm 0,86 \%$ відповідно, $\mathrm{p}<0,001)$. Такі зміни супроводжувалися вірогідним зниженням у пацієнтів is Killip II ХOK

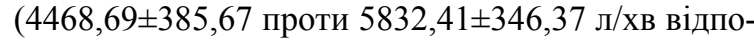
відно, $\mathrm{p}<0,001)$. Виявлено також вірогідне зниження показника ступеня вкорочення передньозаднього розміру порожнини лівого шлуночка $(\Delta \mathrm{S} \%)$ у пацієнтів із Killip II $(22,39 \pm 0,44$ проти

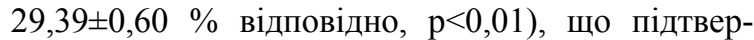
джує наявність у таких осіб порушень скоротливої здатності міокарда. Інші показники ЕхоКГ в обох виділених групах не відрізнялась (p>0,05).

За даними багатьох досліджень, хворі на ГІМ з ознаками ГСН мають несприятливий як короткотривалий, так і віддалений прогноз [9]. Незважаючи на те, що на сучасному етапі впро-

Таблиця 1

Показники внутрішньосерцевої гемодинаміки у хворих на інфаркт міокарда залежно від класу гострої серцевої недостатності (Killip I-II)

\begin{tabular}{|c|c|c|c|c|}
\hline 1. & КДР (см) & $4,90 \pm 0,09$ & $4,74 \pm 0,08$ & $\mathrm{p}>0,05$ \\
\hline 2. & $\mathrm{KCP}(\mathrm{cм})$ & $3,46 \pm 0,07$ & $3,68 \pm 0,08$ & $\mathrm{p}<0,05$ \\
\hline 3. & ТМШПс (см) & $1,11 \pm 0,03$ & $1,11 \pm 0,05$ & $\mathrm{p}>0,05$ \\
\hline 4. & ТМШПд (см) & $1,03 \pm 0,03$ & $0,95 \pm 0,05$ & $\mathrm{p}>0,05$ \\
\hline 5. & ТЗСЛШс (см) & $1,13 \pm 0,03$ & $1,06 \pm 0,05$ & $\mathrm{p}>0,05$ \\
\hline 6. & ТЗСЛШд (см) & $1,04 \pm 0,03$ & $1,08 \pm 0,04$ & $\mathrm{p}>0,05$ \\
\hline 7. & КДО (мл) & $115,13 \pm 5,18$ & $106,16 \pm 7,03$ & $\mathrm{p}>0,05$ \\
\hline 8. & КСО (мл) & $50,57 \pm 2,52$ & $58,30 \pm 3,81$ & $\mathrm{p}<0,05$ \\
\hline 9. & УО (мл) & $64,55 \pm 3,09$ & $47,85 \pm 3,53$ & $\mathrm{p}<0,01$ \\
\hline 10. & ФВ (\%) & $55,99 \pm 0,86$ & $45,05 \pm 0,10$ & $\mathrm{p}<0,001$ \\
\hline 11. & ХОК (л/хв) & $5832,41 \pm 346,37$ & $4468,69 \pm 385,67$ & $\mathrm{p}<0,01$ \\
\hline 12. & $\Delta \mathrm{S} \%$ & $29,39 \pm 0,60$ & $22,39 \pm 0,44$ & $\mathrm{p}<0,01$ \\
\hline 13. & $\Delta \mathrm{T}_{3 \mathrm{c}}(\%)$ & $0,14 \pm 0,03$ & $0,13 \pm 0,04$ & $\mathrm{p}>0,05$ \\
\hline 14. & $\Delta \operatorname{TmH}(\%)$ & $0,15 \pm 0,03$ & $0,14 \pm 0,05$ & $\mathrm{p}>0,05$ \\
\hline 15. & $\Delta \mathrm{p}(\%)$ & $0,39 \pm 0,03$ & $0,43 \pm 0,03$ & $\mathrm{p}>0,01$ \\
\hline 16. & ММЛШ (г) & $187,94 \pm 7,24$ & $177,44 \pm 13,41$ & $\mathrm{p}>0,05$ \\
\hline 17. & IММЛШ $\left(г / \mathrm{M}^{2}\right)$ & $94,81 \pm 3,82$ & $89,05 \pm 6,33$ & $\mathrm{p}>0,05$ \\
\hline 18. & ВТСЛШ & $0,43 \pm 0,01$ & $0,43 \pm 0,02$ & $\mathrm{p}>0,05$ \\
\hline
\end{tabular}

Таблиця 2

Показники нейрогуморальної регуляції у хворих на інфаркт міокарда 3 різними стадіями гострої серцевої недостатності за Killip

\begin{tabular}{|c|c|c|c|c|}
\hline № $\Pi \backslash \Pi$ & Показник & Killip I $(n=91)$ & Killip II $(n=15)$ & $\mathrm{P}$ \\
\hline 1. & Альдостерон (пмоль/л) & $223,33 \pm 9,44$ & $246,92 \pm 8,32$ & $<0,05$ \\
\hline 2. & $\begin{array}{c}\text { Передсердний натрійуретичний } \\
\text { пептид (пг/мл) }\end{array}$ & $54,52 \pm 3,65$ & $66,95 \pm 4,97$ & $<0,05$ \\
\hline 3. & $\begin{array}{c}\text { Ангіотензинперетворюючий } \\
\text { фактор (мкмоль/хв/л) } \\
\end{array}$ & $69,25 \pm 2,95$ & $71,57 \pm 2,66$ & $>0,01$ \\
\hline 4. & Фактор Віллебранда (мг/л) & $1,12 \pm 0,07$ & $1,28 \pm 0,14$ & $>0,05$ \\
\hline
\end{tabular}


Таблиця 3

Коефіцієнт кореляції між показниками функціонального стану міокарда та параметрами активності чинників нейрогуморальної регуляції

\begin{tabular}{|c|c|c|c|c|c|}
\hline $\begin{array}{c}\text { № } \\
\Pi \backslash \Pi\end{array}$ & Показник & $\begin{array}{l}\text { Альдо- } \\
\text { стерон }\end{array}$ & $\begin{array}{c}\text { Ангіотензин- } \\
\text { перетворюючий } \\
\text { фактор }\end{array}$ & $\begin{array}{c}\text { Передсердний } \\
\text { натрійуретичий } \\
\text { пептид }\end{array}$ & $\begin{array}{c}\text { Фактор } \\
\text { Віллебранда }\end{array}$ \\
\hline 1. & КДР (см) & $-0,03$ & 0,01 & $-0,1$ & 0,02 \\
\hline 2. & $\mathrm{KCP}(\mathrm{cm})$ & $-0,04$ & 0,10 & 0,05 & $-0,006$ \\
\hline 3. & ТМШПс (см) & $-0,04$ & $-0,05$ & 0,09 & 0,14 \\
\hline 4. & ТМШПд (см) & 0,08 & $-0,05$ & $-0,09$ & 0,07 \\
\hline 5. & ТЗСЛШс (см) & $-0,03$ & 0,04 & 0,01 & 0,002 \\
\hline 6. & ТЗСЛШд (см) & 0,08 & 0,09 & $-0,06$ & 0,29 \\
\hline 7. & КДО (мл) & $-0,03$ & 0,01 & $-0,1$ & 0,02 \\
\hline 8. & КСО (мл) & 0,10 & $-0,03$ & 0,05 & $-0,002$ \\
\hline 9. & УО (мл) & $-0,0009$ & 0,02 & $-0,20 *$ & 0,04 \\
\hline 10. & ФВ (\%) & 0,01 & $-0,14$ & $-0,27^{* *}$ & $-0,09$ \\
\hline 11. & ХOK (л/хв) & 0,03 & 0,04 & $-0,20^{*}$ & 0,01 \\
\hline 12. & $\Delta \mathrm{S} \%$ & 0,02 & $-0,11$ & $-0,28^{* *}$ & $-0,09$ \\
\hline 13. & $\Delta$ T3с & 0,19 & 0,06 & $-0,03$ & $-0,23 * *$ \\
\hline 14. & $\Delta \mathrm{TmH}$ & $0,27 * *$ & 0,15 & $0,26^{*}$ & $-0,20 *$ \\
\hline 15. & $\Delta \mathrm{p}$ & $-0,04$ & 0,05 & 0,009 & 0,15 \\
\hline 16. & ММЛШ (г) & 0,11 & 0,12 & $-0,13$ & 0,16 \\
\hline 17. & 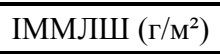 & 0,10 & 0,09 & $-0,12$ & 0,17 \\
\hline 18. & ВТСЛШ & 0,04 & $-0,05$ & 0,02 & 0,16 \\
\hline
\end{tabular}

Примітка. * - коефіцієнт вірогідності р <0,05; ** - < 0,01(наведені тільки статистично вірогідні відмінності)

ваджуються нові хірургічні технологї та адекватна медикаментозна терапія, наявність ГСН у хворих на ГІМ супроводжується підвищенням летальності на 10-30\% протягом 1 року [2, 7]. За даними дослідження EMERALD (Enhanced Myocardial Efficacy and Recovery by Aspiration of Liberated Debris), при ГІМ із ураженням передньої стінки ЛШ спостерігається зниження епікардіального кровотоку та міокардіальної перфузії порівняно 3 іншою локалізацією, що може призводити до виникнення ГСН $[3,9]$.

Отже, наявність у хворих на ГІМ проявів ГСН (Killip II) асоціюється з вірогідно нижчими показниками УО $(\mathrm{p}<0,01)$, ХОК $(\mathrm{p}<0,001)$ та ФВ $(\mathrm{p}<0,001)$.

За використання теорії шансів нами виявлено, що в осіб із Killip II високо вірогідно вища ймовірність зменшення ФВ нижче $50 \%(\mathrm{t}=2,48$; $\mathrm{p}<0,05)$. У цих же хворих вірогідна ймовірність зменшення УО нижче 50 мл $(\mathrm{t}=2,67 ; \mathrm{p}<0,01)$ та ХОК нижче 5000 мл/хв $(\mathrm{t}=2,11 ; \mathrm{p}<0,05)$. Ймовірність зростання КСО понад 54 мл також вірогідно вища в осіб із Killip II ( $\mathrm{t}=1,98 ; \mathrm{p}<0,05)$.

За даними багатоцентрових досліджень, наявність ГСН та зниженої систолічної функції ЛШ $\epsilon$ незалежними факторами ризику несприятливого перебігу ГІМ та розвитку несприятливих проявів хвороби у віддалений період $[3,7]$, а у хворих на ГІМ при збереженій функції ЛШ відміча- ється кращий прогноз порівняно із хворими зі зниженою систолічною функцією. ГСН при ГІМ $\epsilon$ фактором підвищеного ризику раптової смерті та розвитку повторного ГІМ протягом трьох років після перенесеного ГІМ $[4,8]$.

Для оцінки впливу нейрогуморальних месенджерів на розвиток ГСН при IМ нами досліджено рівень цих гормонів у плазмі крові хворих, розподілених за стадіями ГСН за Killip (табл.2). Встановлено, що у хворих на ГСН за Killip II у плазмі крові визначається вірогідно вища концентрація рівня альдостерону $(246,92 \pm 92$ проти 223,33 $\pm 9,44$ пмоль/л, $\mathrm{p}<0,05)$. Це підтверджують дані літератури щодо негативного впливу альдостерону на перебіг ГІМ $[3,6]$. У хворих цієї ж підгрупи виявлено вірогідно вищу концентрацію ПНУП $(66,95 \pm 4,97$ проти 54,52 $\pm 3,65$ пг/мл, $\mathbf{p}<0,05)$, який $\epsilon$ фізіологічним антагоністом альдостерону.

Концентрація у плазмі АПФ у хворих на ГCH за Killip II, хоч і перевищувала аналогічний

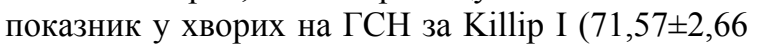
проти $69,25 \pm 2,95$ мкмоль/хв/л, $\mathrm{p}>0,05)$, однак відмінності були статистично невірогідні. Не виявлено також вірогідних відмінностей концентрації у крові ФВб $(1,28 \pm 0,14$ проти $1,12 \pm 0,07$ мГ/ л, $\mathrm{p}>0,05$ ), хоча у підгруп хворих на ГСН за Killip II вона була дещо вищою.

При дослідженні корелятивних зв 'язків між нейрогуморальними чинниками та показниками 
внутрішньосерцевої гемодинаміки виявлено (табл.3), що рівень альдостерону позитивно корелював $3 \Delta \mathrm{TmH}(\mathrm{r}=0,27 ; \mathrm{p}<0,01)$. Концентрація ПНУП від'ємно корелювала з величиною УО (r=$0,21 ; \mathrm{p}<0,05)$, ФВ $(\mathrm{r}=-0,27 ; \mathrm{p}<0,01)$ та ХОК $(\mathrm{r}=-$ $0,21 ; \mathrm{p}<0,05)$. Спостерігався також позитивний корелятивний зв'язок між рівнем ПНУП та $\Delta \mathrm{TmH}(\mathrm{r}=0,27 ; \mathrm{p}<0,05)$. Для ФВб були характерні від'ємні корелятивні зв'язки $3 \Delta \mathrm{TmH}(\mathrm{r}=-0,21$; $\mathrm{p}<0,05)$ та $\Delta \mathrm{T} 3 \mathrm{c}(\mathrm{r}=-0,23 ; \mathrm{p}<0,01)$. Такі результати дещо відрізняються від літературних і зумовлені, певно, індивідуальними особливостями обстежених хворих $[5,6]$.

Таким чином, результати дослідження свідчать, що в обстежених хворих на ГІМ із $\mathrm{CH}$ спостерігається активація РААС, що проявляється у надмірному зростанні концентрації альдостерону та АПФ; стимуляція ендокринної функції серця, що проявляється у зростанні ПНУП та ознак ендотеліальної дисфункції та гіперкоагуляції, відображенням чого є зростання концентрації ФВб. Кожен із цих чинників бере участь у компенсаторно-пристосувальних реакціях при розвитку IM, однак характер змін цих показників свідчить про розвиток у обстежених хворих ознак дискоординації нейрогуморальних механізмів регуляції серцево-судинної системи.

\section{Висновки}

1. Наявність у хворих на гострий інфаркт міокарда проявів гострої серцевої недостатності (Killip II) асоціюється з вірогідно нижчими показниками ударного об'єму ( $<<0,01)$, хвилинного об'єму крові $(\mathrm{p}<0,001), \quad$ фракцією викиду $(\mathrm{p}<0,001)$, вірогідно вищими показниками рівня альдостерону $(\mathrm{p}<0,05)$ та передсердного натрійуретичного пептиду $(\mathrm{p}<0,05)$.

2. Концентрація передсердного натрійуретичного пептиду від'ємно корелювала 3 величинами ударного об'єму крові ( $<00,05)$, фракцією викиду $(\mathrm{p}<0,01)$ та хвилинного об'єму крові $(\mathrm{p}<0,05)$.

Перспективи подальших досліджень. Визначення взаємозв'язку між показниками нейрогуморальної активності з вираженістю процесів пероксидного окиснення, антиоксидантного захи- сту, протеолізу, фібринолізу, які відіграють важливу роль у виникненні та прогресування серцевої недостатності.

\section{Література}

1. Березін О.Є. Мозковий натрійуретичний пептид як маркер раннього післяінфарктного ремоделювання: результати когортного дослідження / О.С. Березін, Т.О. Самура // Укр. кардіол. ж. - 2012. - № 3. - С. 5765.

2. Дзяк Г.В. Досвід використанні спекл-трекінг ехокардіографії для оцінки структурно-функціонального стану серця / Г.В. Дзяк, М.Ю. Колесник // Укр. кардіол. ж. 2012. - № 4. - С. 7-15.

3. Клінічні рекомендації з діагностики та лікування гострої серцевої недостатності: оновлення 2012 року / О.М. Пархоменко, К.М. Амосова, Г.В. Дзяк [та ін.] // [Електронний ресурс] Електронний науково-практ. журнал про кардіол. - 2013. - № 2. - С. 1-30. - Режим доступу до журналу:_strazhesko.org.ua/inc/materials/ gsn_recommend_2012_final.doc.

4. Коваленко В.Н. Ренин-ангиотензиновая система в кардиальной патологии. Часть 2 / В.Н. Коваленко, Т.В. Талаева, В.В. Братусь // Укр. кардіол. ж. - 2012. № 4. - C. $68-84$.

5. Bauersachs J. Pre-clinical data on involvement of mineralocorticoid receptor activation in healing and remodeling post-myocardial infarction / J.Bauersachs, D. Fraccarolo // Eur. Heart J. Suppl. - 2012. - Vol. 13. Suppl.B. - B10-B14.

6. Declining in-hospital mortality and increasing heart failure incidence in elderly patients with first myocardial infarction / J. Ezekowitz, P. Kaul, J. Bakal [et al.] // J. Amer. Coll. Cardiology. - 2012. - Vol. 53, № 1. P. 13-20.

7. Determinants and consequences of renal function variations with aldosterone blocker therapy in heart failure patients after myocardial infarction: insights from the Eplerenone Post-Acute Myocardial Infarction Heart Failure Efficacy and Survival Study / P. Rossignol, J.G. Cleland, S. Bhandari [et al.] // Circulation. - 2012. Vol. 125, № 2. - P. 271-279.

8. Neighborhood socioeconomic disparities 1-year case fatality after incident myocardial infarction: The Atherosclerosis Risk in Communities (ARIC) Community Surveillance (1992-2002) / Randi E. Foraker, Mehul D. Patel, Eric A. Whitsel [et al.] // Am. Heart J. - 2013. - Vol. 165, № 1. - P. 102-107.

9. McMuray J. ESC Guideilnes for the diagnosis and treatment of acute and chronic heart failure $2012 / \mathrm{J}$. McMuray, S. Adaumopolous // Europ. Heart J. - 2012. Vol. 5, № 33. - P. 1787-1847.

\section{РЕГИСТР ИНФАРКТА МИОКАРДА НА СЕВЕРНОЙ БУКОВИНЕ: НЕЙРОГУМОРАЛЬНЫЕ НАРУШЕНИЯ ПРИ ОСТРОЙ СЕРДЕЧНОЙ НЕДОСТАТОЧНОСТИ}

\section{О.И. Гулага, В.К. Тащук, О.С. Полянская}

Резюме. У больных острым инфарктом миокарда с клиническими проявлениями острой сердечной недостаточности (Killip II) обнаружены достоверно низкие показатели ударного объема крови $(\mathrm{p}<0,01)$, минутного объема крови ( $<20,001)$, достоверно высокие показатели уровня альдостерона $(\mathrm{p}<0,05)$ и предсердного натрийуретического пептида $(\mathrm{p}<0,05)$. Обнаружена отрицательная коррелятивная связь концентрации предсердного натрийуретического пептида с величиной ударного объема крови $(\mathrm{p}<0,05)$, фракцией выброса $(\mathrm{p}<0,01)$ минутным объемом крови $(\mathrm{p}<0,05)$.

Ключевые слова: острый инфаркт миокарда, гормоны, эхокардиография. 


\section{REGISTER OF MYOCARDIAL INFARCTION IN NORTHERN BUKOVYNA: NEUROHUMORAL DISORDERS IN ACUTE HEART FAILURE}

\section{O.I. Hulaga, V.K. Tashchuk, O.S. Polianska}

Abstract. In patients with acute myocardial infarction with clinical manifestations of acute heart failure (Killip II) significantly lower rates of the stroke volume of blood $(\mathrm{P}<0,01)$, minute volume of blood $(\mathrm{P}<0,001)$, significantly high indices of the level of aldosterone $(p<0,05)$ and atrial natriuretic peptide $(p<0,05)$. A negative correlative relationship of the atrial natriuretic peptide concentration with the magnitude of the stroke volume of blood $(\mathrm{P}<0,05)$, ejection fraction $(\mathrm{p}<0,01)$ and the minute volume of blood $(\mathrm{P}<0,05)$ has been detected.

Key words: acute myocardial infarction, heart failure, echocardiography, aldosterone

Bukovinian State Medical University (Chernivtsi)

\section{ОСОБЛИВОСТІ МОРФОФУНКЦІОНАЛЬНОГО СТАНУ СЕРЦЯ, СУДИН ТА ЕНДОТЕЛІАЛЬНОЇ ФУНКЦЇ̈ В ОСІБ ІЗ ПОСДНАНИМ ПЕРЕБІГОМ ХРОНІЧНОГО ОБСТРУКТИВНОГО ЗАХВОРЮВАННЯ ЛЕГЕНЬ ТА ГІПЕРТОНІЧНОЇ ХВОРОБИ}

Запорізький державний медичний університет

Резюме. Обстежено 101 хворого на хронічне обструктивне захворювання легень (ХОЗЛ), гіпертонічну хворобу II стадії (ГХ) та їх поєднаним перебігом. За допомогою ехокардіографії та допплерографії визначали параметри систолічної та діастолічної функції лівого i правого шлуночків, товщину комплексу інтима-медіа загальної (ТКІМ) правої та лівої загальної сонної артеpiї (ЗСА), показники стану ендотелію. Виявлено, що в осіб із поєднаним перебігом ХОЗЛ та ГХ спостерігається статистично значуще збільшення ТКІМ правої та

Вступ. За даними наукових джерел, провідною причиною смерті хворих на ХОЗЛ, є розвиток не термінальної дихальної недостатності, а серцево-судинних розладів $[4,7]$. У той же час встановлено, що більше ніж 50 \% хворих на ХОЗЛ має артеріальну гіпертензію [7]. При цьому синхронний перебіг гіпертонічної хвороби (ГХ) та захворювань бронхолегеневої системи виявлено майже в $30 \%$ осіб $[1,2]$.

Мета дослідження. Вивчити особливості морфофункціонального стану міокарда, судин, ендотеліальної функції в осіб із поєднаним перебігом ХОЗЛ ІІ-ІІІ стадії та ГХ ІІ стадії та провести аналіз взаємозв'язків між показниками, які досліджувалися.

Матеріал і методи. Всього обстежено 101 хворого на ХОЗЛ II-III стадії, ГХ ІІ стадії та 3 поєднаним перебігом ХОЗЛ II-III стадії та ГХ II стадії, які перебували на лікуванні в університетській клініці Запорізького державного медичного університету. Критерії включення в до- лівої ЗСА, зниження показника ендотелійзалежної вазодилатації, порушення систолічної та діастолічної функції лівого та правого шлуночків порівняно з хворими, які мали ХОЗЛ або ГХ.

Ключові слова: хронічне обструктивне захворювання легень, гіпертонічна хвороба, морфофункціональні параметри серця, товщина комплексу інтимамедіа, ендотеліальна функція.

слідження: інформована згода пацієнта, наявність ГХ ІІ стадії згідно з рекомендаціями Української асоціації кардіологів від 2011 р., встановлений діагноз ХОЗЛ II-III стадії (наказ МО3 №128 від 12.03.2007 р.), вік від 40 до 65 років. Критерії виключення 3 дослідження: симптоматична артеріальна гіпертензія, серцева недостатність вище за II функціональний клас за NYHA, фібриляція передсердь, тяжка мітральна недостатність, ішемічна хвороба серця, цукровий діабет, новоутворення та системні захворювання сполучної тканини.

Обстежених пацієнтів розподілено на три групи: до 1-ї увійшли 28 хворих на ГХ II стадії, до 2-ї - 27 хворих на ХОЗЛ ІІ-ІІІ стадії, до 3-ї -46 пацієнтів із поєднаним перебігом ХОЗЛ II-III стадії та ГХ ІІ стадії. У пацієнтів із синхронним перебігом діагноз ХОЗЛ, за даними анамнезу, встановлений пізніше, ніж розвиток ГХ. Контрольну групу склали 20 практично здорових осіб. Виділені групи були зіставні за віком та статтю. 